\title{
Termite assemblages in five semideciduous Atlantic Forest fragments in the northern coastland limit of the biome
}

\author{
Heitor Bruno de Araújo Souza ${ }^{1}$, Wagner de França Alves ${ }^{1} \&$ Alexandre Vasconcellos ${ }^{1,2}$
}

${ }^{1}$ Laboratório de Termitologia, Departamento de Sistemática e Ecologia, Universidade Federal da Paraíba, 58051-900 João Pessoa-PB, Brazil.
heitorbrunosouza@gmail.com; wagnerfrancaa@yahoo.com.br; avasconcellos@dse.ufpb.br
${ }^{2}$ Corresponding author

ABSTRACT. Termite assemblages in five semideciduous Atlantic Forest fragments in the northern coastland limit of the biome. Termites are abundant organisms in tropical ecosystems and strongly influence the litter decomposition and soil formation. Despite their importance, few studies about their assemblage structures have been made in Brazilian Atlantic Forest fragments, especially in the area located north of the São Francisco River. This study aims to analyze the assemblage composition of five Atlantic Forest fragments located in the northern biome limit along the Brazilian coast. A standardized sampling protocol of termites was applied in each fragment. Thirty-three termite species belonging to twenty genera and three families were found in the forest fragments. The wood-feeder group was dominant both concerning to species richness and number of encounters in all areas. In sites northern to $7^{\circ} \mathrm{S}$, there is an evident simplification of the termite assemblage composition regarding species richness and number of encounters by feeding group. This fact is apparently due to a higher sandy level in soils and to semideciduous character of the vegetation in the northern fragments. Thus, even on the north of São Francisco River, termite biodiversity is heterogeneously spread with highest density of species in the portion between $07^{\circ} \mathrm{S}$ and São Francisco River mouth (10 $\left.29^{\prime} \mathrm{S}\right)$.

KEYWORDS. Biodiversity; Brazil; feeding groups; Isoptera; Neotropical Region.

RESUMO. Taxocenoses de térmitas em cinco fragmentos de Mata Atlântica semidecíduas no limite costeiro norte de distribuição do bioma. Os térmitas são organismos abundantes nos ecossistemas tropicais, influenciando fortemente os processos de decomposição da necromassa vegetal e de formação de solos. Apesar de sua importância, poucos estudos sobre a composição das suas taxocenoses foram realizados em fragmentos do complexo Mata Atlântica, especialmente no setor localizado ao norte do Rio São Francisco. O objetivo deste estudo foi analisar a composição das taxocenoses de térmitas em cinco fragmentos de Mata Attântica situados no limite norte litorâneo de distribuição do bioma na América do Sul. Um protocolo padronizado de amostragem termítica foi aplicado em cada fragmento. Trinta e três espécies, pertencentes a 20 gêneros e três famílias, foram encontradas nos cinco fragmentos de Mata Atlântica. O grupo dos consumidores de madeira foi o dominante em todas as áreas, em termos de riqueza de espécies e número de encontros. Abaixo do $7^{\circ} \mathrm{S}$ há uma clara simplificação da composição das taxocenoses de térmitas, relacionada à riqueza de espécies e número de encontro por grupos alimentares. Este fato deve-se aparentemente ao maior teor de areia nos solos e ao caráter semidecidual da vegetação presente nos fragmentos localizados no extremo norte. Desta forma, mesmo no setor ao norte do Rio São Francisco, a biodiversidade de térmitas está heterogeneamente distribuída, com maior densidade de espécies na porção entre $07^{\circ} \mathrm{S}$ e a foz do Rio São Francisco (10²9'S).

PALAVRAS-CHAVE. Biodiversidade; Brazil; grupos tróficos; Isoptera; Região Neotropical.

Termites are social insects which belong to the order Isoptera containing approximately 2,900 described species (Constantino 2011). They are one of the most abundant animals of tropical ecosystems with their biomass in Neotropical forests reaching more than $10 \mathrm{~g}$ fresh weight $/ \mathrm{m}^{2}$ (Martius 1998). Termites possess a great ability to digest cellulose that allows them to redirect a considerable proportion of the energy flow (Wood \& Sands 1978). Therefore such organisms are important to the maintenance of the dynamic of litter decomposition processes and flows of energy and nutrients in these ecosystems (Bustamante \& Martius 1998; Vasconcellos \& Moura 2010). Furthermore, the alterations caused by termite activities on the soil profile influence the availability of resources to organisms belonging to other feeding categories (Lavelle et al. 1997). The elimination of termites from an ecosystem may, therefore, cause the loss of species that depend on them for survival or reproduction (Constantino \& Acioli 2006).

Despite the ecological importance of termites, few studies have been developed into assemblage structures of these insects in Brazilian Northeast region, especially in Caatinga and Atlantic Forest complex ecosystems (Bandeira et al. 1998; Bandeira et al. 2003; Mélo \& Bandeira 2004; Vasconcellos 2010; Vasconcellos et al. 2010).

Atlantic Forest complex is the second largest rainforest in the Neotropical region (Tabarelli et al. 2005). The Atlantic Forest covered originally 1,360,000 $\mathrm{km}^{2}$ that corresponds about to $15 \%$ of Brazilian territory. Nowadays, duo to more than five hundred years of human disturbance, $88.3 \%$ of the original Atlantic Forest coverage has been lost (Ribeiro et al. 2009). This fact leads to a reduction of extremely rich biological resource habitats (MMA 2002). The situation is criti- 
cal on the north of Sao Francisco River in the Northeast region of Brazil, where the largest part of Atlantic Forest was converted into agricultural lands having $12.1 \%$ of the original coverage left (Ribeiro et al. 2009).

This study aims to describe the composition of termite assemblages with regard to the species richness, number of encounters and feeding groups in five semideciduous Atlantic Forest fragments, all of them located on the north of São Francisco River and near to the northern coast limit of biome.

\section{MATERIAL AND METHODS}

Study sites. This study took place in five fragments of semideciduous Atlantic Forest situated on the north of São Francisco River. (I) Parque Estadual das Dunas. It is located in Rio Grande do Norte state capital, Natal (05'50'S and $35^{\circ} 10^{\prime} \mathrm{W}$ ) and covers an area of $1,172.80$ ha. It is mainly composed by dune formations, semideciduous forest and savanna-like vegetation locally known as "tabuleiros", being part of Biological Reserve of Brazilian Atlantic Forest (Freire 1990). The Parque Estadual das Dunas presents an annual average temperature around to $26^{\circ} \mathrm{C}$ and annual precipitation from $1,200 \mathrm{~mm}$ to $2,000 \mathrm{~mm}$. (II) Mata do Jiqui. It is located in Parnamirim city $\left(05^{\circ} 56^{\prime} \mathrm{S}\right.$ and $\left.35^{\circ} 11^{\prime} \mathrm{W}\right)$, Rio Grande do Norte state and covers an area of 79 ha and presents vegetation classified as semideciduous forest. It presents an annual average temperature around $26.4^{\circ} \mathrm{C}$ and annual average precipitation of $1,466 \mathrm{~mm}$. (III) Floresta Nacional de Nísia Floresta. It is situated in the municipality of Nísia Floresta $\left(06^{\circ} 05^{\prime} \mathrm{S}\right.$ and $\left.35^{\circ} 12^{\prime} \mathrm{W}\right)$, Rio Grande do Norte state and covers 170ha (Castro 2003). The annual average temperature is $27.1^{\circ} \mathrm{C}$ and the annual average precipitation is $1,442.8 \mathrm{~mm}$ (MME 2005). (IV) Mata do Bastião. It is located in the municipality of Tibau do Sul $\left(06^{\circ} 13^{\prime} \mathrm{S}\right.$ and $\left.35^{\circ} 04^{\prime} \mathrm{W}\right)$, Rio Grande do Norte state and covers approximately 50ha. This fragment has vegetation classified as semideciduous forest and presents an annual average temperature around $24^{\circ} \mathrm{C}$ and an annual average precipitation of 1,500 $\mathrm{mm}$ (Monteiro et al 2006).(V) Reserva Biológica Guaribas. It is situated in Paraíba state between Rio Tinto and Mamanguabe cities $\left(06^{\circ}\right.$ $44^{\prime}$ and $35^{\circ} 08^{\prime} \mathrm{W}$ ) and covers an area of 4,321 ha. This area is divided into three fragments, but this study was conducted in the largest of them, that covers 3,319.09 ha. The vegetation is classified as semideciduous forest. Its average annual temperature is $25^{\circ} \mathrm{C}$ and its annual average precipitation is around 1,470 mm (Governo do Estado da Paraíba 1985).

Sampling protocol. Intending to elaborate a termite assemblage inventory, a termite standardized sampling protocol was applied in each fragment. The protocol consisted of six random $65 \times 2 \mathrm{~m}$ transect demarcations distributed throughout the study area on sites with apparent absence of human disturbances. In each transect, five plots of $5 \times 2 \mathrm{~m}$ each were demarcated, at a distance of $10 \mathrm{~m}$ from each other, totalizing 30 plots $\left(300 \mathrm{~m}^{2}\right)$ by fragment. A sampling time at each plot was $1 \mathrm{~h} /$ person. In other words, if two people collect in a plot, each one should spend 30 minutes there, total- izing one hour of searching. During this time, termites were searched up to $15 \mathrm{~cm}$ depth in the soil, in the nests (all active or abandoned), tree trunks and fallen branches, under the litter-leaf and tree barks and in dead roots.

The collected samples were stored in labeled glass jars containing $75 \%$ alcohol, and deposited in the Isoptera Collection of Universidade Federal da Paraíba.

Feeding groups. The species were categorized by feeding groups based on in situ observations as well as on available literature about Neotropical termites, especially from the Atlantic Forest on the north of São Francisco River (Bandeira et al. 1998; Bandeira et al. 2003; Vasconcellos et al. 2005; Vasconcellos 2010). The species were classified as: (i) wood feeders, individuals which eat wood in different stages of decomposition; (ii) humus feeders, feeding on humus and usually living into soil profile; (iii) wood and humus feeders, feeding on wood and humus in different stages of decomposition and usually carrying soil into the wood they are consuming; (iv) wood and leaf feeders, individuals which eat twigs and leaves that make up the litter.

Analyses. Rarefaction curves were elaborated using Maotau Method for each area, having been inserted 95\% confidence intervals out of 1,000 randomizations without replacement of original data. Analyses were done with software Estimates 7.5 (Colwell 2005).

\section{RESULTS}

It was found a total of 33 species belonging to 20 genera and three families within the five fragments of Atlantic Forest (Table I). Eight species were common to all areas. The family Termitidae was the dominant in number of species (27; 81.8\%), being followed by Kalotermitidae (4; 12.1\%) and Rhinotermitidae $(2 ; 6.1 \%)$. Regarding the subfamilies, Nasutitermitinae was dominant in number of species and frequency of occurrences in the plots. In most fragments, the feeding group of wood-feeders was dominant, both in number of species (39\% to $61 \%)$ and frequency of occurrences ( $45 \%$ to $71 \%$ ) (Fig. 1$)$.

The species that build conspicuous nests were Armitermes holmgreni (Snyder, 1926), Labiotermes labralis (Holmgreni, 1965), Microcerotermes exiguus (Hagen, 1958), M. strunckii (Sörensen, 1884), Nasutitermes corniger (Motchulsky, 1855), N. ephratae (Holmgren, 1910), N. macrocephalus (Silvestre, 1903) e Nasutitermes sp. Despite Embiratermes neotenicus had been collected in the Reserva Biológica Guaribas, their mounds were not found in the area.

The termite assemblage rarefaction curves of Parque das Dunas, Mata do Jiqui, Mata do Bastião and Floresta Nacional de Nísia Floresta were similar, with their upper limits of the confidence intervals varying from 14.4 to 17.2 species. On the other hand, the curve that was elaborated using the data of the termite assemblage of Reserva Biológica Guaribas was significantly different from those which were built using data from the other areas and it presented a strong tendency for rising (Fig. 2). 

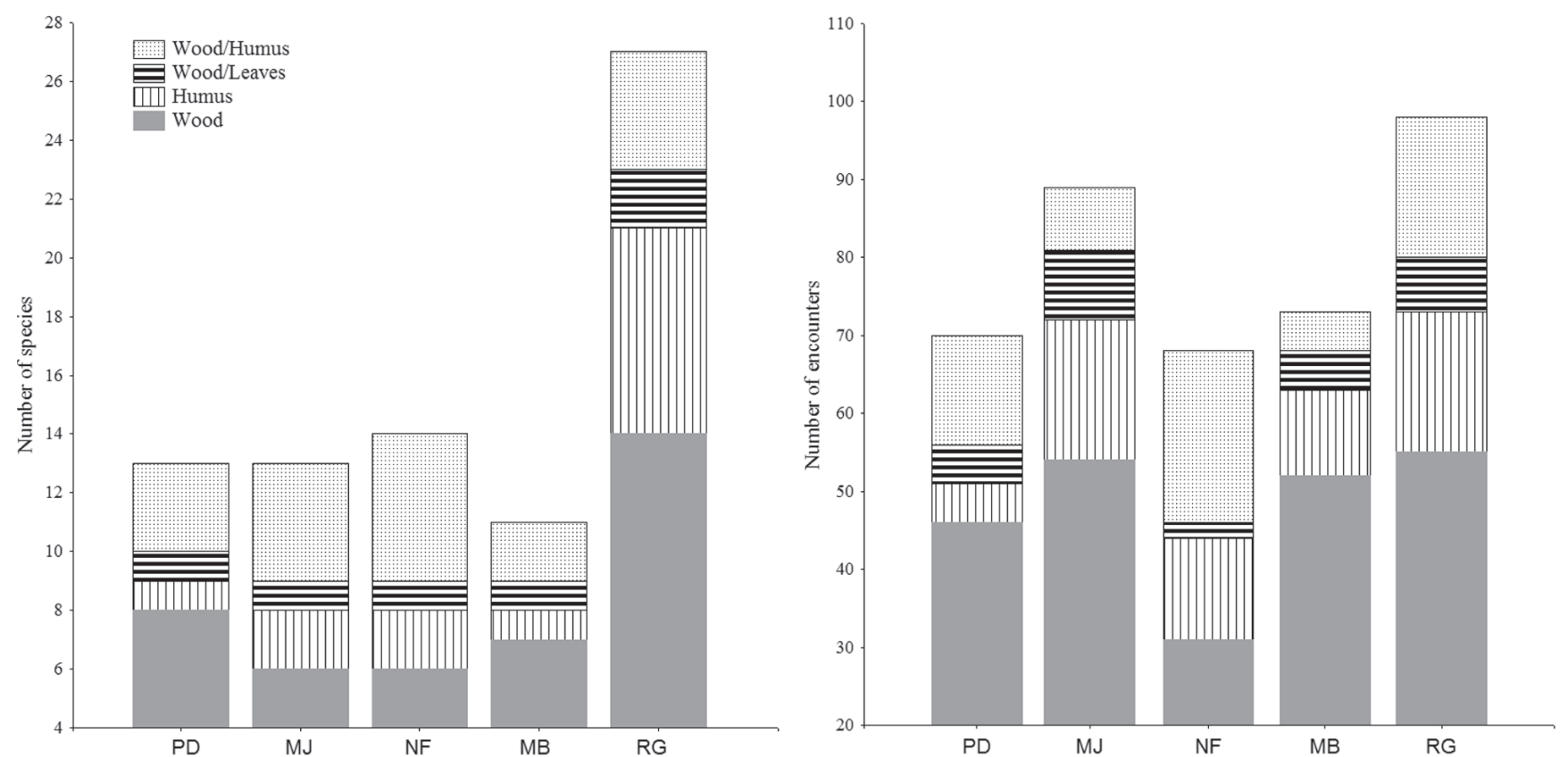

Fig. 1. Number of termite species and occurrences belonging to each feeding group in the five Atlantic Forest fragments. Fragments: PD, Parque Estadual das Dunas; MJ, Mata do Jiqui; NF, Floresta Nacional de Nísia Floresta; MB, Mata do Bastião; RG, Reserva Biológica Guaribas.

\section{DISCUSSION}

Having added the 18 species which were determined to the species level in this study, we have currently a total of 31 termite species in the whole Atlantic Forest (Bandeira et al. 1998; Brandão 1998; Silva \& Bandeira 1999; Vasconcellos et al. 2005; Reis \& Cancello 2007; Vasconcellos 2010). Considering only the region situated on the north of São Francisco River, considered an endemism center of this biome (Prance 1982; Silva et al. 2004), we have a total of 24 termite species which were determined to the species level. If we consider all studies about termite assemblages in the Atlantic Forest, the number of non-determined species varied from $27 \%$ to $88 \%$, suggesting that there could have a reasonable number of nondescribed species (Bandeira et al. 1998; Brandão 1998; Vasconcellos et al. 2005; Reis \& Cancello 2007; Vasconcellos 2010). Bandeira et al. (1998) estimated the existence of approximately 26 genera and 60 species of termites for the Atlantic Forest situated on the north of São Francisco River, with more than half of these species being new to science.

The fact that the subfamily Nasutitermitinae is dominant in terms of number of occurrences and species richness is consistent with other published studies on the fauna of termites in Atlantic Forest (Bandeira et al. 1998; Brandão 1998; Vasconcellos et al. 2005; Reis \& Cancello 2007; Vasconcellos 2010). The family Kalotermitidae presented the lowest number of occurrences, but this is due to a probable underestimation, since most of its colonies live inside hardwood or in the region of canopy, making more difficult the collection of the individuals (Roisin et al. 2006; Reis \& Cancello 2007).

The wood feeders are the feeding group which presented the greatest number of species, corroborating the pattern observed in other studies conducted in the Atlantic Forest, where this group dominance ranges between $43 \%$ and $64 \%$ of total species richness (Bandeira et al. 1998; Brandão 1998; Vasconcellos et al. 2005; Reis \& Cancello 2007). On the other hand, in terms of abundance, Vasconcellos (2010) found a dominance of humus feeders in three Atlantic Forest remnants north to São Francisco River. Thus, group high species richness is not always directly linked to its high abundance and biomass in this ecosystem.

Conspicuous nests belonging to eight termite species were found in the five remnants that were studied. Besides these species, in the north sector of the São Francisco River, we can find conspicuous nests of Anoplotermes banksi and Embiratermes neotenicus, totalizing 10 species which build conspicuous nests throughout this sector (Vasconcellos et al. 2005; Vasconcellos et al. 2008; Vasconcellos 2010). Nine of these species build arboreal nests or nests in direct contact with living trees. $E$. neotenicus is the only one that builds mound nests.

The simplifications of the assemblages concerning to species richness, with decreasing degrees of latitude go against the general established pattern for biodiversity (Willig et al. 2003) and richness of termite genera (Eggleton 1994). Lowering $7^{\circ} \mathrm{S}$ latitude, the Atlantic Forest vegetation is established mainly in sandy soils with low capacity to retain water and nutrients, and a large proportion of the plant species possessing a semideciduous character (IBGE 1992; Cestaro 2002). Commonly, high sand content soils (>85\%) provide less stability for building tunnels and underground nests by termites, which apparently prefer more clayey soils (Lee \& Wood 1971). In arboreal resting forests of northeast Brazil, Vasconcellos et al. (2005) associated the low species richness of Apicotermitinae and the humus feeders to the 

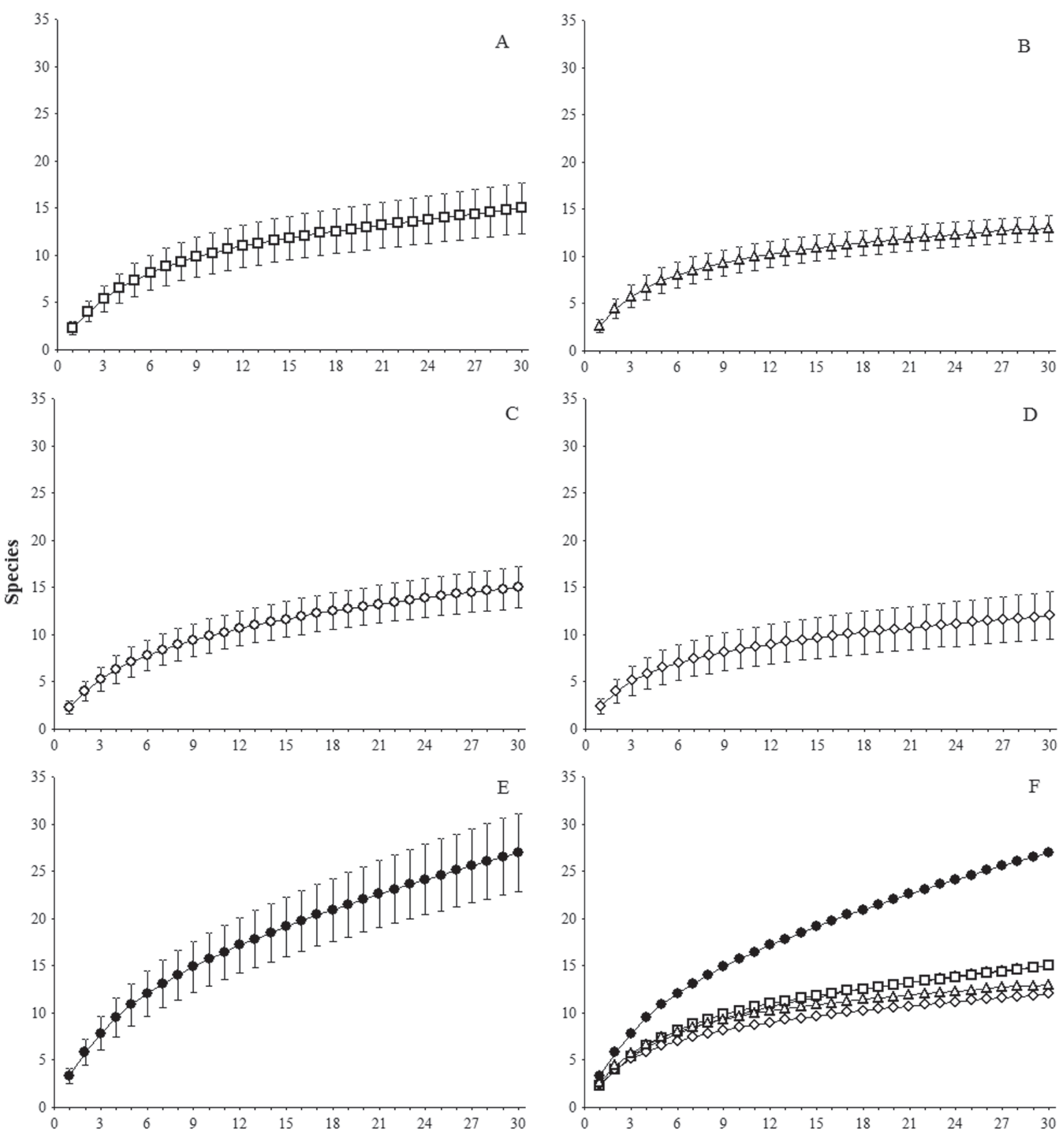

Quadrats

Fig. 2. Curves of species accumulation in the five fragments studied. A, Parque Estadual das Dunas; B, Mata do Jiqui; C, Floresta Nacional de Nísia Floresta; D, Mata do Bastião; E, Reserva Biológica Guaribas; F, Comparing the five fragments.

soil properties related to the low contents of clay and organic matter. The low retention of water and nutrients in sandy soils is usually followed by a lower primary productivity of the ecosystem and, consequently, by a lower production of litter, reducing the availability of resources for detritivore organisms, such as termites (Chapin III et al. 2002). Moreover, the water low availability in the soil profile can affect the de- composition of litter and be restrictive for many invertebrates which depend directly or indirectly on this process (Swift et al. 1979; Lavelle et al.1995).

In short, the biodiversity of termites is not homogeneously distributed in the Atlantic Forest area on the north of São Francisco River and the portion below $7^{\circ} \mathrm{S}$ latitudinal poor in species richness, number of encounters (surrogates to relative 
Table I. Termite species that were found in the five Atlantic Forest fragments of Northeast Brazil. Numbers represent the encounters. W, wood; S, subterraneous; L, litter; A, arboreal, I, inquiline.

\begin{tabular}{|c|c|c|c|c|c|c|c|}
\hline Species & $\begin{array}{c}\text { Parque das } \\
\text { Dunas }\end{array}$ & $\begin{array}{c}\text { Mata do } \\
\text { Jiqui }\end{array}$ & $\begin{array}{c}\text { Nísia } \\
\text { Floresta }\end{array}$ & $\begin{array}{c}\text { Mata do } \\
\text { Bastião }\end{array}$ & Guaribas & Nesting & Feeding group \\
\hline \multicolumn{8}{|l|}{ Kalotermitidae } \\
\hline Neotermes sp. 1 & 1 & & & 1 & & $\mathrm{~W}$ & Wood \\
\hline Neotermes sp. 2 & & & & 1 & & $\mathrm{~W}$ & Wood \\
\hline Rugitermes sp. 1 & 1 & & & & 3 & $\mathrm{~W}$ & Wood \\
\hline Tauritermes sp. 1 & & & & & 1 & $\mathrm{~W}$ & Wood \\
\hline \multicolumn{8}{|l|}{ Rhinotermitidae } \\
\hline Coptotermes testaceus (Linnaeus) & & & & & 1 & $\mathrm{~S}$ & Wood \\
\hline Heterotermes longiceps (Snyder) & 6 & 15 & 2 & 10 & 9 & $\mathrm{~S}$ & Wood \\
\hline \multicolumn{8}{|l|}{ Termitidae } \\
\hline \multicolumn{8}{|l|}{ Apicotermitinae } \\
\hline Anoplotermes sp. 1 & 5 & 17 & 12 & 11 & 11 & $\mathrm{~S}$ & Humus \\
\hline Anoplotermes sp. 2 & & & & & 1 & $\mathrm{~S}$ & Humus \\
\hline Anoplotermes sp. 3 & & & & & 1 & $\mathrm{~S}$ & Humus \\
\hline Aparatermes sp. 1 & & & & & 2 & $\mathrm{~S}$ & Humus \\
\hline Aparatermes sp. 2 & & & & & 1 & $\mathrm{~S}$ & Humus \\
\hline Grigiotermes sp. & & 1 & & & & $\mathrm{~S}$ & Humus \\
\hline Ruptitermes sp. & & & & & 1 & $\mathrm{~S}$ & Wood/Leaves \\
\hline \multicolumn{8}{|l|}{ Nasutitermitinae } \\
\hline Armitermes holmgreni (Snyder) & 1 & 1 & & & 8 & A & Wood/Humus \\
\hline Diversitermes sp. 1 & 5 & 9 & 1 & 5 & 3 & $\mathrm{~L}$ & Wood/Leaves \\
\hline Embiratermes neotenicus(Holmgren) & & & & & 1 & $\mathrm{~S}$ & Humus \\
\hline Labiotermes labralis (Holmgreni) & & & 1 & & 1 & A & Humus \\
\hline Nasutitermes callimorphus Mathews & 11 & 11 & 14 & 19 & 13 & $\mathrm{~L}$ & Wood \\
\hline Nasutitermes corniger (Motschulsky) & 8 & 3 & 6 & 5 & 5 & A & Wood \\
\hline Nasutitermes ephratae (Holmgren) & & & & & 1 & $\mathrm{~W}$ & Wood \\
\hline Nasutitermes gaigei Emerson & & & & & 5 & W & Wood \\
\hline Nasutitermes longirostratus (Holmgren) & & & & & 1 & $\mathrm{~W}$ & Wood \\
\hline Nasutitermes macrocephalus (Silvestri) & 1 & 6 & 1 & & 1 & A & Wood \\
\hline Nasutitermes sp. 1 & & & & & 1 & & Wood \\
\hline Velocitermes sp. 1 & & & 1 & & 3 & $\mathrm{~L}$ & Wood/1Leaves \\
\hline \multicolumn{8}{|l|}{ Termitinae } \\
\hline Amitermes amifer (Silvestri) & 9 & 5 & 5 & 4 & 9 & $\mathrm{~W}$ & Wood/Humus \\
\hline Amitermes nordestinus Melo \& Fontes & & & 2 & & & $\mathrm{~W}$ & Wood/Humus \\
\hline Cylindrotermes sapiranga Rocha \& Cancello & 1 & 2 & 1 & 2 & 1 & $\mathrm{~W}$ & Wood \\
\hline Microcerotermes exiguus (Hagen) & 17 & 17 & 7 & 14 & 12 & $\mathrm{~A} / \mathrm{W}$ & Wood \\
\hline Microcerotermes strunckii (Sorensen) & & & & & 1 & $\mathrm{~A} / \mathrm{W}$ & Wood \\
\hline Neocapritermes opacus (Hagen) & 4 & 1 & 3 & 1 & & $\mathrm{~W} / \mathrm{S}$ & Wood/Humus \\
\hline Termes sp. 1 & & 1 & & & 1 & $\mathrm{~W}$ & Wood/Humus \\
\hline Termes medioculatus Emerson & & & 12 & & & $\mathrm{I}$ & Wood/Humus \\
\hline Total of species & 13 & 13 & 14 & 11 & 27 & & \\
\hline Total of encounters & 70 & 89 & 68 & 73 & 98 & & \\
\hline
\end{tabular}

abundance) and species for feeding groups. We formulated the hypothesis that the distribution of termites in the Atlantic Forest, situated on the north of the São Francisco River, is apparently affected by clay content in the soil up to $30 \mathrm{~cm}$ depth and the semideciduous character of the vegetation.

\section{ACKNOWLEDGMENTS}

To Adriano S. Mota, Ruy A. A. Lima and Rodrigo Bellezoni for their assistance in field samplings. To the managers of
Reserva Biológica Guaribas, Parque Estadual das Dunas do Natal, Floresta Nacional de Nísia Floresta and Mata do Jiqui (EMPARN).

\section{REFERENCES}

Bandeira, A. G.; J. C. D. Pereira; C. S. Miranda \& L. G. S. Medeiros. 1998. Composição da fauna de cupins (Insecta: Isoptera) em áreas de Mata Atlântica em João Pessoa, Paraíba, Brasil. Revista Nordestina de Biologia 12: 9-17. 
Bandeira, A. G.; A. Vasconcellos; M. P. Silva \& R. Constantino. 2003. Effects of habitat disturbance on the termite fauna in a highland humid forest in the Caatinga domain, Brazil. Sociobiology 42: 117-127.

Brandão, D. 1998. Patterns of the termite (Isoptera) diversity in the Reserva Florestal de Linhares, State of Espírito Santo, Brazil. Revista Brasileira de Entomologia 41: 151-153.

Bustamante, N. C. R. \& C. Martius. 1998. Nutritional preferences of woodfeeding termites inhabiting floodplain forests of the Amazon River, Brazil. Acta Amazonica 28: 301-307.

Castro, C. S. S. 2003. Tamanho da área de vida e padrão de uso do espaço em grupos de sagüis Callithrix jacchus (Linneaus) (Primates, Callitrichidae). Revista Brasileira de Zoologia 20: 91-96.

Cestaro, L. A. 2002. Fragmentos de Florestas Atlânticas no Rio Grande do Norte: Relações Estruturais, Florísticas e Fitogeográficas. Tese de doutorado, São Carlos, Universidade Federal de São Carlos, 256 p.

Chapin III, F.S.; P. A. Matson \& H. A. Mooney. 2002. Principles of terrestrial ecosystem ecology. New York, Springer, 436 p.

Colwell, R. K. 2005. EstimateS: Statistical estimation of species richness and shared species from samples, version 7.5. Available at: http:// purl.oclc.org/estimates (accessed 15th April 2011).

Constantino, R. 2011. On-line termite database. Available from: http:// www.termitologia.unb.br (accessed 17th September 2011).

Constantino, R. \& A. N. S. Acioli. 2006. Termite diversity in Brazil (Insecta: Isoptera), p. 117-128. In: F. M. S. Moreira, J. O. Siqueira, L. Brussaard (eds.). Soil Biodiversity in Amazonian and Other Brazilian Ecosystems. Wallingforg, CAB International, 280 p.

Eggleton, P. 1994. Termites live in a pear shaped world: a response to Platnick. Journal of Natural history 28: 1209-1212.

Freire, M. S. B. 1990. Levantamento florístico do Parque Estadual das Dunas do Natal. Acta Botanica Brasilica 4: 41-59.

Governo do Estado da Paraíba. 1985. Atlas Geográfico do Estado da Paraíba. João Pessoa, Grafset, 100 p.

IBGE - Instituto Brasileiro de Geografia e Estatística. 1992. Manual técnico da vegetação brasileira. Rio de Janeiro (Série Manuais Técnicos de Geociências, número 1), 92 p.

Lavelle, P.; C. Lattaud, D. Lattaud \& I. Barois. 1995. Mutualism and biodiversity in soils. Plant Soil 170: 23-33.

Lavelle, P.; D. Bignell; M. Lepage; V. Wolters; P. Roger; P. Ineson; O. W. Heal \& S. Dhillion. 1997. Soil function in a changing world: the role of invertebrate ecosystem engineers. European Journal of Soil Biology 33: $159-193$.

Lee, K. E. \& T. G. Wood. 1971. Termites and soils. London, Academic Press, $251 \mathrm{p}$.

Martius, C. 1998. Occurrence, body mass and biomass of Syntermes spp. (Isoptera: Termitidae) in Reserva Ducke, Central Amazonia. Acta Amazonica 28: 319"324.

Mélo, A. C. S. \& A. G. Bandeira. 2004. A qualitative and quantitative survey of termites (Isoptera) in an open Shrubby Caatinga in Northeast Brazil. Sociobiology 44: 707-716.

MME - Ministério de Minas e Energia. 2005. Projeto cadastro de fontes de abastecimento por água subterrânea. Diagnóstico do município de Nísia Floresta, estado do Rio Grande do Norte. Recife, MME/ CPRM, 145 p.

MMA - Ministério do Meio Ambiente. 2002. Biodiversidade Brasileira Avaliação e identificação das áreas prioritárias para a conservação, utilização sustentável e repartição dos benefícios da biodiversidade dos biomas brasileiros. Brasília, MMA/SBF, $404 \mathrm{p}$.

Monteiro, M. S.; A. Souto \& L. F. do Nascimento. 2006. Comparações entre comportamentos de forrageio nas diferentes faixas etárias do botocinza (Sotalia guianensis) (Cetacea; delphinidae) na Baía dos Golfinhos, Praia de Pipa-RN-Brasil. Revista de Etologia 8: 13-25.

Prance, G.T. 1982. Forest refuges: evidence from woody angiosperms, p. 137-158. In: G. T. Prance (ed.). Biological diversification in the tropics. New York, Columbia University Press, xvi+714 p.

Reis, Y. T. \& E. M. Cancello. 2007. Riqueza de cupins (Insecta, Isoptera) em áreas de Mata Atlântica primária e secundária do sudeste da Bahia. Iheringia, Serie Zoologia, 97: 229-234.

Ribeiro M. C.; J. P. Metzger; A. C. Martensen; F. J. Ponzoni \& M. M. Hirota. 2009. The Brazilian Atlantic Forest: How much is left, and how is the remaining forest distributed? Implications for conservation. Biological Conservation 142: 1141-1153.

Roisin, Y.; A. Dejean; B. Corbara; J. Orivel; M. Samaniego \& M. Leponce. 2006. Vertical stratification of the termite assemblage in a neotropical rainforest. Oecologia 149: 301-311.

Silva, E. G. \& A. G. Bandeira. 1999. Abundância e distribuição vertical de cupins (Insecta, Isoptera) em solo de Mata Atlântica, João Pessoa, Paraíba, Brasil. Revista Nordestina de Biologia 13: 13-36.

Silva, J. M. C.; M. C. Souza \& C. H. M. Castelletti. 2004. Areas of endemism for passerine birds in Atlantic forest, South America. Global Ecology and Biogeography 13: 85-92.

Swift, M. J.; O. W. Heal \& J. M. Anderson. 1979. Decomposition in terrestrial ecosystems. Oxford, Blackwell Scientific Publications, xii+ 384 p.

Tabarelli, M.; L. P. Pinto; J. M. C. Silva; M. Hirota \& L. Bede. 2005. Challenges and opportunities for Biodiversity conservation in the Brazilian Atlantic forest. Conservation Biology 19: 695-700.

Vasconcellos, A. 2010. Biomass and abundance of termites in three remnant areas of Atlantic Forest in northeastern Brazil. Revista Brasileira de Entomologia 54: 455-461.

Vasconcellos, A \& F. M. S. Moura. 2010. Wood litter consumption by three species of Nasutitermes termites in an area of the Atlantic Coastal Forest in northeastern Brazil. Journal of Insect Science 10:72. Available at: http://www.insectscience.org/10.72/11536-2442-10-72.pdf (accessed 11th September 2011).

Vasconcellos, A.; A. C. S. Mélo; E. M. V. Segundo \& A. G. 2005. Cupins de duas florestas de restinga do Nordeste Brasileiro. Iheringia, Série Zoologia, 95: 127-131.

Vasconcellos, A.; A. G. Bandeira; W. O. Almeida; F. M. S. Moura. 2008. Termites that build conspicuous nests in two areas of Atlantic forest under different levels of anthropogenic disturbance. Neotropical Entomology 37: 15-19.

Vasconcellos, A.; A. G. Bandeira; F. M. S. Moura; V. F. P. Araújo; M. A. B. Gusmão \& R. Constantino. 2010. Termite Assemblages in three habitats under different disturbance regimes in the semi-arid Caatinga of NE Brazil. Journal of Arid Environments 74: 298-302.

Willig, M.R.; D. M. Kaufman \& R. D. Stevens. 2003. Latitudinal gradients of biodiversity: pattern, process, scale and synthesis. Annual Review of Ecology, Evolution and Systematics 34: 273-309.

Wood, T.G. \& W.A. Sands. 1978. The role of termites in ecosystems, p. 245"292. In: M.V. Brian (ed). Production ecology of ants and termites. Cambridge, Cambridge University Press, 350 p.

Received 22/4/2011; accepted 13/12/2011

Editor: Gustavo Graciolli 